\title{
Residual Effects of Organic Manure on Onion Varieties' Mineral Content
}

\author{
Şafak Ceylan ${ }^{1, a, *}$, Funda Yoldaş ${ }^{1, b}$, Nilgün Saatçı Mordoğan ${ }^{2, c}$ \\ ${ }^{1}$ Organic Agriculture Programme, Odemis Technical Training College, Ege University, 35750 Izmir, Turkey \\ ${ }^{2}$ Soil Science and Plant Nutrition Department, Faculty of Agriculture, Ege University, 35040 Izmir, Turkey \\ *Corresponding author \\ A R T I C L I N F O A B S T R A T

\section{Research Article} \\ Received : 25/05/2020 \\ Accepted : 17/09/2020 \\ Keywords: \\ Onion \\ Variety \\ Chicken manure \\ Nutrient content \\ Macro and microelements \\ This study was conducted to determine the residual effects of chicken manure applications on \\ nutrients in leaves and bulbs of second crop onion that grown after lettuce in greenhouse conditions. \\ In the study, residual effects of chicken manure in 4 different doses (control, $20 \mathrm{t} \mathrm{ha}^{-1}, 40 \mathrm{t} \mathrm{ha}^{-1}, 60$ \\ $\mathrm{t} \mathrm{ha}^{-1}$ ) and chemical fertilizers applied in the recommended amounts are investigated. Three onion \\ varieties, called Burgaz, Snow white, Champion, were used. In the study, the lowest nutrient uptake \\ was observed in control. However, the highest mineral content in leaves and bulbs were determined \\ in the plots, that on average $40 \mathrm{t} \mathrm{ha}^{-1}$ chicken manure was applied to. In terms of leaf nutrient \\ content, when the varieties were compared to each other, $\mathrm{Ca}, \mathrm{Mg}$, and $\mathrm{Cu}$ contents were found to \\ be the highest in the Burgaz variety. Phosphorus, $\mathrm{Zn}, \mathrm{Mn}$ contents were analyzed to be the highest \\ in Snow white while $\mathrm{N}$ values determined maximum in Champion. The Champion variety contained \\ higher nutrient values in bulbs. \\ safak.ceylan@ege.edu.tr \\ nilgun.mordogan@ege.edu.tr

\section{Introduction}

Organic manure is essential for the sustainability of crop production and soil fertility. At the same time, its agricultural input is used in organic farming, which is preferred for a healthy life and environmental awareness (Eleroglu and Korkmaz, 2016). Organic material such as chicken manure improves soil's physical, chemical, and biological properties that are important for plant growth (Snyman et al., 1998). The decomposition of materials would provide additional nutrients to the growing medium, which may lead to higher uptake of nutrients by the crop and subsequently to high yield. Besides, organic manures have a positive effect on root growth by improving the root rhizosphere conditions (such as structure and humidity), and also plant growth is encouraged by increasing the population of microorganisms (Shaheen et al., 2007; Kidanu, 2017). The organic fertilizers hold plant nutrients that promote enzymes and hormones, besides plant nutrients make them necessary for the enhancement of soil fertility and production (Bhuma, 2001). Organic manure added to soil leaves a substantial amount of residual nutrients to succeed crop. Besides, it is supplying nutrients to the current crop (Suthamathy and Seran, 2013). Some studies have reported that organic manures have significant residual effects on the soil and succeeding crop (Yoldaş et al., 2019; Yoldaş et al., 2020). According to Aydeniz et al.
(1977), Aydeniz and Brohi (1991), 65\% of N, 50\% of P, and $75 \%$ of $\mathrm{K}$ in poultry manure have become available within the first year application. In another study, Whitmore (2007) found that $40 \%$ of the total $\mathrm{N}$ from composted chicken manure was available in the first year, with the remainder available in subsequent years at a rate of $6 \%$ to $12 \%$ per year.

A residual effect of manure application study has reported where excessive rates of manure are applied (Lund and Doss, 1980). Ginting et al. (2003) did not find increased emission of greenhouse gasses $\left(\mathrm{CO}_{2}, \mathrm{CH}_{4}\right.$, and $\mathrm{N}_{2} \mathrm{O}$ ) as a result of residual manure and compost applications that ceased 4 year earlier.

Onion bulb is a rich source of minerals like $\mathrm{P}, \mathrm{Ca}, \mathrm{Mg}$, $\mathrm{Fe}, \mathrm{Mn}$, and carbohydrates. It also contains protein, Vitamin C, Vitamin B6, and antioxidants.

Onions are produced in our country as widely as possible According to the statistics; Turkey's bulb onion production is 1930695 tons over 53000 hectare area (Anonymous, 2018).

The objective of this study is to evaluate the residual effects of different doses of chicken manure on second crop onion (Allium cepa L.) varieties' mineral and sucrose, fructose, glucose content in the in the greenhouse condition. 


\section{Materials and Methods}

The study was carried out in the greenhouse condition at the Ödemiş Vocational School of the Ege University, in İzmir (38 $\left.16^{\prime} \mathrm{N}, 27^{\circ} 59^{\prime} \mathrm{E}\right)$ during the year 2017. The experimental designs were split plot with three replications. Before sowing of lettuce, the chicken manure was applied to the soil at the rates of $0-20-40-60 \mathrm{t} \mathrm{ha}^{-1}$ and also recommended dose of NPK (150:100:150 kg ha-1). Five different treatments with control and three replications were conducted in 15 plots. Lolla Rossa variety of lettuce was sown and harvested at the end of vegetation. After harvesting the lettuce plant, onion varieties were sown in order to determine the residual effects of chicken manure and chemical fertilizer in the greenhouse conditions. No nutrient addition was made to chicken manure was applied to plots. In this study, during the growth period, weeds were removed by hand hoeing, and irrigation was done regularly.

Three onion varieties called Burgaz, Snow white, Champion were used. Allium cepa L. was planted in each plot with $30 \mathrm{~cm}$ between rows and $15 \mathrm{~cm}$ above the rows. The total plot length is $11.5 \mathrm{~m}$, and the plot width is $6.2 \mathrm{~m}$.

Soil samples $(0-20 \mathrm{~cm})$ were collected from the individual experimental plots ( 15 samples) at the beginning of onion vegetation. The sample was air-dried, grounded and passed through a $2 \mathrm{~mm}$ sieve for the determination of chemical parameters (Kacar,1984).

Some physical and chemical characteristics of soils, determined by standard analytical methods specified in Klute (1986) and Page et al. (1982). Available K, Ca, Na flame photometer (Eppendorf) and $\mathrm{Mg}, \mathrm{Fe}, \mathrm{Zn}, \mathrm{Mn}, \mathrm{Cu}$ by atomic absorption spectrophotometer (AAS; Varian AA 240 FS) (Lindsay and Norvell, 1978; Atalay et al., 1986).

Leaf samples were taken before the onion bulbs became not to the stage of maturity as the youngest leaves for chemical analyses (Jones et al., 1991). After the leaf and bulb samples were taken from plots, and dried in $70^{\circ} \mathrm{C}$, ready for analyses (Kacar, 1972). In the study, total nitrogen was analyzed according to the modified method of Kjeldahl (Bremner, 1965). After the wet digestion of samples, the phosphorus content was determined by the colorimetric method (Lott et al., 1956). Potassium, calcium, and sodium contents were analyzed by flame fotometer; $\mathrm{Mg}, \mathrm{Fe}, \mathrm{Zn}, \mathrm{Mn}$, and $\mathrm{Cu}$ amount were measured by the AAS (Munoz, 1968; Kacar, 1972). The trial statistical evaluation result of data was done using software package TARIST (Acikgoz et al., 1993).

\section{Results and Discussion}

\section{Soil Properties}

The physical and chemical properties of soils before onion sowing are presented in Tables 2 and 3. Chicken manure and mineral fertilizer applications significantly improved the total $\mathrm{N}$ percentage of the soils $(\mathrm{P}<0.01)$. The maximum $\mathrm{N}$ content of greenhouse soils was determined in the plots in which the chicken manure was applied as 40 $\mathrm{t} \mathrm{ha}^{-1}$. Similar the results Ayed (2002); Adenawoola and Adejoro (2005); Davis et al., (2006); Dikinya (2010), explained that $\mathrm{N}$ content in the soil was significantly increased by chicken manure application because of the nitrogenous compounds that are found in the chicken manure which is released during decomposition.
On the contrary, $\mathrm{pH}$, organic matter, lime, $\mathrm{P}, \mathrm{K}, \mathrm{Ca}, \mathrm{Mg}$, $\mathrm{Na}, \mathrm{Fe}, \mathrm{Zn}, \mathrm{Mn}, \mathrm{Cu}$ values in the soil did not show any statistical difference between applications at the beginning of vegetation. However, Egball at al. (2004), no residual effects of manure and compost treatments on $\mathrm{pH}$, total $\mathrm{C}$ and $\mathrm{N}$ concentration were observed in the $15-30 \mathrm{~cm}$ soil depth.

The composition of chicken manure that residual effect investigated was analyzed according to Kacar (1995) and is presented in Table 1.

Table 1. Some properties of chicken manure.

\begin{tabular}{l|r}
\hline \multicolumn{1}{c|}{ Properties } & \multicolumn{1}{|c}{ Value } \\
\hline $\mathrm{pH}$ & 8.55 \\
Total Salt $(\mathrm{ms} / \mathrm{cm})$ & 2.47 \\
Ash 550 ${ }^{\circ} \mathrm{C}(\%)$ & 79 \\
Organic Matter $(\%)$ & 19.8 \\
Organic Carbon $(\%)$ & 11.51 \\
Total N $(\%)$ & 0.95 \\
$\mathrm{C} / \mathrm{N}$ & 12.1 \\
$\mathrm{P}(\%)$ & 0.70 \\
$\mathrm{~K}(\%)$ & 1.02 \\
$\mathrm{Ca}(\%)$ & 1.37 \\
$\mathrm{Mg}(\mathrm{ppm})$ & 3729 \\
$\mathrm{Na}(\mathrm{ppm})$ & 1248 \\
\hline
\end{tabular}

Table 2. Some properties of greenhouse soils at the beginning of onion vegetation.

\begin{tabular}{l|ccc}
\hline \multicolumn{1}{c|}{ Treatment } & $\mathrm{pH}$ & O.M. (\%) & $\mathrm{CaCO}_{3}(\%)$ \\
\hline 0 & 7.24 & 1.57 & 0.92 \\
$\mathrm{NPK}$ & 7.25 & 1.47 & 0.43 \\
$20 \mathrm{t} \mathrm{ha}^{-1}$ & 7.44 & 1.61 & 0.86 \\
$40 \mathrm{t} \mathrm{ha}^{-1}$ & 7.29 & 1.33 & 0.42 \\
$60 \mathrm{t} \mathrm{ha}^{-1}$ & 7.15 & 1.47 & 0.36 \\
LSD & n.s. & n.s. & n.s. \\
\hline **: P<0.01, *: P<0.05, n.s.: not significant
\end{tabular}

\section{Mineral Contents of Onion Leaves}

Residue effects of chicken manure doses on the nutrient content of onion leaf as the second crop after the lettuce production are given in Table 4. Nitrogen, $\mathrm{P}, \mathrm{Ca}, \mathrm{Mg}, \mathrm{Fe}$, $\mathrm{Zn}, \mathrm{Cu}$ contents in onion leaves increased significantly depending on the residue effects of the chicken manure doses and chemical fertilizer compared to control plot $(\mathrm{P}<0.01)$. Lowest nutrients uptake was observed in control. However, the highest mineral content in leaves was determined in the plots, in which the chicken manure was applied as $40 \mathrm{t} \mathrm{ha}^{-1}$ generally. These results could be explained by the positive effect of chicken manure on improving the nutritional status of the soil, also, due to the rapid mineralization of organic matter (Yassen and Khalid, 2009). Also, Eghball et al. (2003) found that the increased plant-available P level in soil following N-based manure or compost application can contribute to crop P uptake for up to $10 \mathrm{yrs}$. without any additional $\mathrm{P}$ addition.

Similarly, Shaymaa et al. (2014) reported that organic matter represented in cattle manure was important to obtain the highest, chemical constituent and mineral composition that will lead to the best quality in onion plants. Ceylan et al. (2017) stated that P, K, Ca, Mg, Fe, Cu, Zn and Mn contents in lettuce increased significantly with chicken manure applications. 
Bergmann (1993) gave sufficient values as percentages for onion leaves as $\mathrm{N}: 2.0$ to $3.0, \mathrm{P}: 0.25$ to $0.40, \mathrm{~K}: 2.5$ to 3.0, Ca: 0.6 to 1.5 and $\mathrm{Mg}: 0.25$ to 0.50 , and according to this, the leaves in the experiment indicated sufficient levels of $\mathrm{N}, \mathrm{Ca}, \mathrm{Mg}$ elements (Table 4). However, although the nitrogen is insufficient in the soil before planting, it is noteworthy that the leaves are at a sufficient level. This result may be due to the slow release of organic fertilizers and their effects on the following products. Similarly, Murphy (2014) explained that soil organic matter influences a range of functional soil physical, chemical, and biological properties and plays a vital role in nutrient cycling. In the study, although the soils are rich in phosphorus, the leaves are insufficient. Sometimes it may be due to the organic materials in soils that cause negative effects, and also it may create an organo-mineral complex that reduces the availability of some minerals (Sezen, 1995). Besides, K, Mn and $\mathrm{Cu}$ content in leaves except for the plots in which the chicken manure was applied as $20 \mathrm{t}$ $\mathrm{ha}^{-1}$ in the soil found below sufficient level.

Table 3. Nutrient contents of greenhouse soils at the beginning of vegetation.

\begin{tabular}{|c|c|c|c|c|c|}
\hline \multirow{2}{*}{ Treatment } & Total N & $\mathrm{P}$ & $\mathrm{K}$ & $\mathrm{Ca}$ & $\mathrm{Mg}$ \\
\hline & $(\%)$ & $\left(\mathrm{mg} \mathrm{kg}^{-1}\right)$ & $\left(\mathrm{mg} \mathrm{kg}^{-1}\right)$ & $\left(\mathrm{mg} \mathrm{kg}^{-1}\right)$ & $\left(\mathrm{mg} \mathrm{kg}^{-1}\right)$ \\
\hline 0 & $0.056^{\mathrm{c}}$ & 51.30 & 104.4 & 1386 & 323 \\
\hline NPK & $0.078^{\mathrm{ab}}$ & 56.35 & 133.5 & 1023 & 305 \\
\hline $20 \mathrm{t} \mathrm{ha}^{-1}$ & $0.067^{\mathrm{bc}}$ & 60.51 & 133.4 & 1254 & 303 \\
\hline $40 \mathrm{t} \mathrm{ha}^{-1}$ & $0.084^{\mathrm{a}}$ & 63.45 & 136.4 & 1188 & 318 \\
\hline $60 \mathrm{t} \mathrm{ha}^{-1}$ & $0.081^{\mathrm{ab}}$ & 62.05 & 146.5 & 1221 & 308 \\
\hline LSD & $0.015^{* *}$ & n.s. & n.s & n.s & n.s \\
\hline \multirow{2}{*}{ Treatment } & $\mathrm{Na}$ & $\mathrm{Fe}$ & $\mathrm{Zn}$ & $\mathrm{Mn}$ & $\mathrm{Cu}$ \\
\hline & $\left(\mathrm{mg} \mathrm{kg}^{-1}\right)$ & $\left(\mathrm{mg} \mathrm{kg}^{-1}\right)$ & $\left(\mathrm{mg} \mathrm{kg}^{-1}\right)$ & $\left(\mathrm{mg} \mathrm{kg}^{-1}\right)$ & $\left(\mathrm{mg} \mathrm{kg}^{-1}\right)$ \\
\hline 0 & 35.3 & 29.49 & 5.30 & 14.57 & 2.92 \\
\hline NPK & 26.0 & 23.16 & 4.40 & 12.93 & 2.73 \\
\hline $20 \mathrm{t} \mathrm{ha}^{-1}$ & 25.8 & 23.51 & 4.71 & 13.45 & 2.65 \\
\hline $40 \mathrm{t} \mathrm{ha}^{-1}$ & 32.0 & 27.13 & 4.72 & 13.91 & 2.78 \\
\hline $60 \mathrm{t} \mathrm{ha}^{-1}$ & 57.7 & 23.58 & 5.33 & 14.31 & 2.83 \\
\hline LSD & n.s & n.s & n.s & n.s & n.s \\
\hline
\end{tabular}

**: $\mathrm{P}<0.01, *: \mathrm{P}<0.05$, n.s.: not significant

Table 4. Residual effects of chicken manure on nutrient content of onion leaf

\begin{tabular}{|c|c|c|c|c|c|}
\hline \multirow{2}{*}{ Treatment } & Total N & $\mathrm{P}$ & $\mathrm{K}$ & $\mathrm{Ca}$ & $\mathrm{Mg}$ \\
\hline & $(\%)$ & $\left(\mathrm{mg} \mathrm{kg}^{-1}\right)$ & $\left(\mathrm{mg} \mathrm{kg}^{-1}\right)$ & $\left(\mathrm{mg} \mathrm{kg}^{-1}\right)$ & $\left(\mathrm{mg} \mathrm{kg}^{-1}\right)$ \\
\hline 0 & $2.11^{\mathrm{c}}$ & $0.13^{\mathrm{b}}$ & 1.93 & $0.94^{\mathrm{b}}$ & $0.49^{c}$ \\
\hline NPK & $2.52^{\mathrm{a}}$ & $0.19^{\mathrm{ab}}$ & 2.29 & $1.24^{\mathrm{ab}}$ & $0.57^{\mathrm{ab}}$ \\
\hline $20 \mathrm{t} \mathrm{ha}^{-1}$ & $2.32^{\mathrm{b}}$ & $0.16^{\mathrm{ab}}$ & 2.19 & $1.15^{\mathrm{ab}}$ & $0.53^{\mathrm{bc}}$ \\
\hline $40 \mathrm{t} \mathrm{ha}^{-1}$ & $2.45^{\mathrm{a}}$ & $0.22^{\mathrm{a}}$ & 2.65 & $1.41^{\mathrm{a}}$ & $0.62^{\mathrm{a}}$ \\
\hline $60 \mathrm{t} \mathrm{ha}^{-1}$ & $2.52^{\mathrm{a}}$ & $0.22^{\mathrm{a}}$ & 2.37 & $1.21^{\mathrm{ab}}$ & $0.58^{\mathrm{ab}}$ \\
\hline LSD & $0.079^{* *}$ & $0.062^{* *}$ & n.s. & $0.318^{*}$ & $0.071^{* *}$ \\
\hline \multirow{2}{*}{ Treatment } & $\mathrm{Na}$ & $\mathrm{Fe}$ & $\mathrm{Zn}$ & $\mathrm{Mn}$ & $\mathrm{Cu}$ \\
\hline & $\left(\mathrm{mg} \mathrm{kg}^{-1}\right)$ & $\left(\mathrm{mg} \mathrm{kg}^{-1}\right)$ & $\left(\mathrm{mg} \mathrm{kg}^{-1}\right)$ & $\left(\mathrm{mg} \mathrm{kg}^{-1}\right)$ & $\left(\mathrm{mg} \mathrm{kg}^{-1}\right)$ \\
\hline 0 & 819.1 & $68.8^{\mathrm{b}}$ & $17.28^{\mathrm{b}}$ & 18.63 & $2.59^{c}$ \\
\hline NPK & 853.0 & $99.6^{\mathrm{a}}$ & $21.59^{\mathrm{a}}$ & 23.61 & $4.08^{\mathrm{ab}}$ \\
\hline $20 \mathrm{t} \mathrm{ha}^{-1}$ & 955.6 & $85.3^{\mathrm{ab}}$ & $19.72^{\mathrm{ab}}$ & 22.17 & $3.20^{\mathrm{bc}}$ \\
\hline $40 \mathrm{t} \mathrm{ha}^{-1}$ & 1095.1 & $89.0^{\mathrm{ab}}$ & $21.23^{\mathrm{a}}$ & 22.18 & $4.30^{\mathrm{a}}$ \\
\hline $60 \mathrm{t} \mathrm{ha}^{-1}$ & 1079.7 & $96.4^{\mathrm{a}}$ & $21.42^{\mathrm{a}}$ & 23.77 & $3.89^{\mathrm{ab}}$ \\
\hline LSD & n.s. & $20.44^{* * *}$ & $2.547^{* *}$ & n.s. & $0.938^{* *}$ \\
\hline
\end{tabular}

**: $\mathrm{P}<0.01, *: \mathrm{P}<0.05$, n.s.: not significant

$\underline{\text { Table 5. Effect of variety on nutrient content of onion leaf as second crop depending on residue effect of chicken manure }}$

\begin{tabular}{l|ccccc}
\hline \multirow{2}{*}{ Variety } & $\mathrm{N}$ & $\mathrm{P}$ & $\mathrm{K}$ & $\mathrm{Ca}$ & $\mathrm{Mg}$ \\
\cline { 2 - 6 } & $(\%)$ & $(\%)$ & $(\%)$ & $(\%)$ & $(\%)$ \\
\hline Burgaz & $2.35^{\mathrm{b}}$ & $0.18^{\mathrm{b}}$ & 2.32 & $1.43^{\mathrm{a}}$ & $0.59^{\mathrm{a}}$ \\
Kar Beyaz1 & $2.38^{\mathrm{ab}}$ & $0.21^{\mathrm{a}}$ & 2.40 & $1.11^{\mathrm{b}}$ & $0.57^{\mathrm{ab}}$ \\
Şampiyon & $2.42^{\mathrm{a}}$ & $0.16^{\mathrm{b}}$ & 2.15 & $1.03^{\mathrm{b}}$ & $0.52^{\mathrm{b}}$ \\
\hline LSD & $0.059^{* *}$ & $0.026^{* *}$ & $\mathrm{n} . \mathrm{s}$. & $0.164^{* *}$ & $0.049^{* *}$ \\
\hline \multirow{2}{*}{ Variety } & $\mathrm{Fe}$ & $\mathrm{Zn}$ & $\mathrm{Mn}$ & $\mathrm{Cu}$ & $\mathrm{Na}$ \\
& $\left(\mathrm{mg} \mathrm{kg}^{-1}\right)$ & $\left(\mathrm{mg} \mathrm{kg}^{-1}\right)$ & $\left(\mathrm{mg} \mathrm{kg}^{-1}\right)$ & $\left(\mathrm{mg} \mathrm{kg}^{-1}\right)$ & $\left(\mathrm{mg} \mathrm{kg}^{-1}\right)$ \\
\hline Burgaz & 86.8 & $19.45^{\mathrm{b}}$ & $21.17^{\mathrm{ab}}$ & $4.51^{\mathrm{a}}$ & 979.5 \\
Kar Beyaz1 & 85.5 & $21.37^{\mathrm{a}}$ & $24.17^{\mathrm{a}}$ & $3.24^{\mathrm{b}}$ & 1031.2 \\
Şampiyon & 91.0 & $19.93^{\mathrm{ab}}$ & $20.88^{\mathrm{b}}$ & $3.08^{\mathrm{b}}$ & 870.8 \\
\hline LSD & n.s. & $1.858^{*}$ & $3.185^{*}$ & $0.928^{* *}$ & $\mathrm{n} . \mathrm{s}$. \\
\hline **: $\mathrm{P}<0.01 *$ P $<0.05, \mathrm{n}$. s. not significant & & & &
\end{tabular}


In the study, it was determined that leaf nutrient content varies significantly according to the varieties of onion (Table 5). Calcium, $\mathrm{Mg}$, and $\mathrm{Cu}$ content in leaves were found to be the highest in the Burgaz variety $(\mathrm{P}<0.01)$. Phosphorus, $\mathrm{Zn}$, Mn contents in leaves was found to be the highest in Snow white while $\mathrm{N}$ values determined in maximum in Champion variety.

\section{Mineral Contents of Onion Bulb}

The effects of chicken manure doses and varieties on the nutrient content of onion bulbs are shown in Tables 6 and 7. Applications significantly increased mineral concentration in onion bulbs compared to control except $\mathrm{Cu}(\mathrm{P}<0.01)$ (Table 6). In the study, the highest $\mathrm{P}, \mathrm{Mg}, \mathrm{Na}$, $\mathrm{Fe}, \mathrm{Zn}, \mathrm{Mn}$ content in onion bulbs were determined in plots with the residual effect of 40-60 t ha ${ }^{-1}$ doses of chicken manure, while the highest $\mathrm{N}$ contents were reached with mineral fertilizer applications. In $\mathrm{K}$ and $\mathrm{Ca}$ values, no significant difference was found among applications. Similarly, Yoldas et al. (2011) reported that the K content of onion bulbs increased significantly in cattle manure applications in the first year, but $\mathrm{N}, \mathrm{P}, \mathrm{Ca}, \mathrm{Mg}, \mathrm{Fe}, \mathrm{Zn}, \mathrm{Cu}$, $\mathrm{Mn}$ and $\mathrm{Na}$ amounts of onions were not significantly affected by manure applications. However, In the second year, the researchers reported that the manure applications only significantly increased $\mathrm{Na}$ content of the bulb. Abdelrazzag (2002) found that increasing the rate of the sheep and chicken manure increased $\mathrm{N}$ content of onion significantly, while $\mathrm{P}$ and $\mathrm{K}$ contents had a low level. Mahmoud et al. (2013) found that the chemical constituents (N, P, K, and total protein) significantly increased by increasing the level of compost application up to $180 \mathrm{~kg} \mathrm{~N} / \mathrm{fed}$ in sandy soil. Also, Ceylan et al. (2016) reported that organic fertilizer applications had an important effect on olive nutrition, especially in poor soils with organic matter, and increased $\mathrm{N}, \mathrm{K}, \mathrm{Mg}$ content in leaves and $\mathrm{N}, \mathrm{P}, \mathrm{K}, \mathrm{Mg}$ in fruits. In another study, the researchers explained that farmyard manure increased $\mathrm{N}$, $\mathrm{Mg}, \mathrm{Fe}, \mathrm{Zn}$ amounts in watermelon leaves and $\mathrm{N}, \mathrm{P}, \mathrm{Mg}$, $\mathrm{Zn}$ in fruit (Ceylan et al., 2005). These results may be due to the capacity of soil organic matter to influence a range of functional soil physical, chemical, and biological properties and to play an essential role in nutrient cycling (Murphy, 2014).

In the study the ranking of nutrient elements based on their established amount in the examined onion bulbs was $\mathrm{N}>\mathrm{K}>\mathrm{P}>\mathrm{Mg}>\mathrm{Ca}>\mathrm{Na}>\mathrm{Fe}>\mathrm{Zn}>\mathrm{Mn}>\mathrm{Zn}$.

When the effect of varieties on onion bulb nutrient content was investigated, it was determined that $\mathrm{N}$ contents of Champion varieties were significantly higher than other varieties $(\mathrm{P}<0.01)$. $\mathrm{P}$ and Fe content in bulbs of Champion and Snow white varieties were analysed higher than Burgaz variety $(\mathrm{P}<0.01)$. Also, $\mathrm{Cu}$ content was determined significantly at higher values in Snow white and Burgaz varieties than Champion variety (Table 7).

Table 6. Residual effects of chicken manure on nutrient content of onion bulb

\begin{tabular}{|c|c|c|c|c|c|}
\hline \multirow{2}{*}{ Treatment } & Total N & $\mathrm{P}$ & $\mathrm{K}$ & $\mathrm{Ca}$ & $\mathrm{Mg}$ \\
\hline & $(\%)$ & $\left(\mathrm{mg} \mathrm{kg}^{-1}\right)$ & $\left(\mathrm{mg} \mathrm{kg}^{-1}\right)$ & $\left(\mathrm{mg} \mathrm{kg}^{-1}\right)$ & $\left(\mathrm{mg} \mathrm{kg}^{-1}\right)$ \\
\hline 0 & $1.63^{\mathrm{e}}$ & $0.17^{\mathrm{c}}$ & $0.98^{\mathrm{b}}$ & $0.097^{\mathrm{b}}$ & $0.160^{\mathrm{b}}$ \\
\hline NPK & $2.08^{\mathrm{a}}$ & $0.25^{\mathrm{ab}}$ & $1.25^{\mathrm{a}}$ & $0.134^{\mathrm{a}}$ & $0.187^{\mathrm{ab}}$ \\
\hline $20 \mathrm{t} \mathrm{ha}^{-1}$ & $1.73^{\mathrm{d}}$ & $0.20^{\mathrm{bc}}$ & $1.24^{\mathrm{a}}$ & $0.128^{\mathrm{a}}$ & $0.190^{\mathrm{ab}}$ \\
\hline $40 \mathrm{t} \mathrm{ha}^{-1}$ & $1.86^{\mathrm{c}}$ & $0.23^{\mathrm{ab}}$ & $1.25^{\mathrm{a}}$ & $0.149^{\mathrm{a}}$ & $0.202^{\mathrm{a}}$ \\
\hline $60 \mathrm{t} \mathrm{ha}^{-1}$ & $1.98^{\mathrm{b}}$ & $0.27^{\mathrm{a}}$ & $1.35^{\mathrm{a}}$ & $0.152^{\mathrm{a}}$ & $0.199^{\mathrm{a}}$ \\
\hline LSD & $0.072^{* *}$ & $0.059^{* *}$ & $0.015^{* *}$ & $0.031^{* *}$ & $0.032^{*}$ \\
\hline \multirow{2}{*}{ Treatment } & $\mathrm{Na}$ & $\mathrm{Fe}$ & $\mathrm{Zn}$ & $\mathrm{Mn}$ & $\mathrm{Cu}$ \\
\hline & $\left(\mathrm{mg} \mathrm{kg}^{-1}\right)$ & $\left(\mathrm{mg} \mathrm{kg}^{-1}\right)$ & $\left(\mathrm{mg} \mathrm{kg}^{-1}\right)$ & $\left(\mathrm{mg} \mathrm{kg}^{-1}\right)$ & $\left(\mathrm{mg} \mathrm{kg}^{-1}\right)$ \\
\hline 0 & $186.3^{\mathrm{c}}$ & $28.31^{\mathrm{b}}$ & $16.20^{\mathrm{b}}$ & $16.37^{\mathrm{b}}$ & 2.80 \\
\hline NPK & $217.3^{c}$ & $37.15^{\mathrm{a}}$ & $21.77^{\mathrm{a}}$ & $18.42^{\mathrm{ab}}$ & 3.89 \\
\hline $20 \mathrm{t} \mathrm{ha}^{-1}$ & $247.5^{b c}$ & $34.28^{\mathrm{ab}}$ & $19.56^{\mathrm{ab}}$ & $18.86^{\mathrm{a}}$ & 3.60 \\
\hline $40 \mathrm{t} \mathrm{ha}^{-1}$ & $301.3^{\mathrm{ab}}$ & $37.64^{\mathrm{a}}$ & $23.45^{\mathrm{a}}$ & $19.51^{\mathrm{a}}$ & 3.75 \\
\hline $60 \mathrm{t} \mathrm{ha}^{-1}$ & $353.6^{\mathrm{a}}$ & $34.47^{\mathrm{ab}}$ & $22.23^{\mathrm{a}}$ & $19.28^{\mathrm{a}}$ & 3.92 \\
\hline LSD & $62.743^{* *}$ & $6.366^{* *}$ & $4.828^{* *}$ & $2.20^{* * *}$ & ns. \\
\hline
\end{tabular}

**: $\mathrm{P}<0.01, *: \mathrm{P}<0.05$, n.s.: not significant

Table 7. Effect of variety on nutrient content of onion bulb as second crop

\begin{tabular}{l|ccccc}
\hline \multirow{2}{*}{ Variety } & Total N & $\mathrm{P}$ & $\mathrm{K}$ & $\mathrm{Ca}$ & $\mathrm{Mg}$ \\
\cline { 2 - 6 } & $(\%)$ & $\left(\mathrm{mg} \mathrm{kg}^{-1}\right)$ & $\left(\mathrm{mg} \mathrm{kg}^{-1}\right)$ & $\left(\mathrm{mg} \mathrm{kg}^{-1}\right)$ & $\left(\mathrm{mg} \mathrm{kg}^{-1}\right)$ \\
\hline Burgaz & $1.65^{\mathrm{c}}$ & $0.16^{\mathrm{b}}$ & 1.28 & 0.12 & 0.18 \\
Snow White & $1.83^{\mathrm{b}}$ & $0.23^{\mathrm{a}}$ & 1.19 & 0.14 & 0.18 \\
Champion & $2.08^{\mathrm{a}}$ & $0.23^{\mathrm{a}}$ & 1.17 & $\mathrm{n} .13$ & 0.19 \\
\hline LSD & $0.072^{* *}$ & $0.036^{* *}$ & $\mathrm{n} . \mathrm{s}$. & $\mathrm{Mn}$. \\
\hline \multirow{2}{*}{ Variety } & $\mathrm{Na}$ & $\mathrm{Fe}$ & $\mathrm{Zn}$ & $\left(\mathrm{mg} \mathrm{kg}^{-1}\right)$ & $\left(\mathrm{mg} \mathrm{kg}^{-1}\right)$ \\
\cline { 2 - 6 } & $\left(\mathrm{mg} \mathrm{kg}^{-1}\right)$ & $\left(\mathrm{mg} \mathrm{kg}^{-1}\right)$ & 19.29 & 18.39 & $3.85^{\mathrm{a}}$ \\
Burgaz & 244.5 & $29.22^{\mathrm{b}}$ & 21.85 & 18.18 & $4.04^{\mathrm{a}}$ \\
Snow White & 260.0 & $39.12^{\mathrm{a}}$ & 20.79 & 18.89 & $2.89^{\mathrm{b}}$ \\
Champion & 278.9 & $34.77^{\mathrm{a}}$ & $\mathrm{ns.}$ & $\mathrm{n} . \mathrm{s}$. & $0.718^{* *}$ \\
\hline LSD & n.s. & $5.541^{* *}$ & & & \\
\hline
\end{tabular}

**: $\mathrm{P}<0.01, *: \mathrm{P}<0.05$, n.s.: not significant 
The nutrient content of Burgaz variety is lower than $\mathrm{Cu}$. No significant difference was found among the cultivars in terms of $\mathrm{K}$ and $\mathrm{Fe}$ content. The different mineral composition of onion varieties grown in the same conditions may result from genotypic variations between varieties (Chope and Terry, 2009).

In the study, generally, the highest nutrient contents on leaves and bulbs were obtained with the residual effect of $40 \mathrm{t}$ $\mathrm{ha}^{-1}$ doses of chicken manure. Champion varieties had more response to the organic manure compared to the other onion varieties about nutrient content in bulbs. The Champion varieties contained higher nutrient values in bulbs.

In terms of the leaf nutrient content, when the varieties compared to each other, $\mathrm{Ca}, \mathrm{Mg}$, and $\mathrm{Cu}$ content is found to be the highest in the Burgaz variety. Phosphorus, $\mathrm{Zn}, \mathrm{Mn}$ content is analyzed to be the highest in Snow white, while, $\mathrm{N}$ values determined maximum in Champion variety.

Organic fertilizers are slow-release fertilizers, and their effects on soil fertility are seen in the following years and crops. As observed in our study, considering their subsequent effects, it is important to use them consciously with an environmentalist approach.

\section{Acknowledgment}

This research is a work supported by Scientific Research Project Commission of Ege University; Contact no: 2017/OMYO/001

\section{References}

Abdelrazzag A. 2002. Effect of Chicken Manure, Sheep Manure and Inorganic Fertilizer on Yield and Nutrients Uptake by Onion. Pakistan J Biol. Sci. 5(3): 266-268.

Aydeniz A, Teceren M, Dündar M. 1977. Domates veriminde tavuk dışkısının yeri ve 2-Kloro- 6 (Triklorometil) pridinin buna Etkisi. A:Ü:Z:F.27;23-25.

Ayed A. 2002. Effect of chicken manure, sheep manure and inorganic fertilizer on yield and nutrient uptake by onion. Pakistan Jour. of Biological Science 5(3): 266-268.

Adenawoola AR, Adejoro SA. 2005. Residual effects of poultry manure and NPK fertilizer residues on soil nutrient and performance of Jute (Corchorus olitorius L). Niger. J. Soil Sci. 15: 133-135.

Acikgoz N, Atas ME, Moghaddam A, Ozcan K. 1994. Tarist. Proceeding of The National Congress on Field Crop Plants, Izmir, Turkey, pp. 264-267. April 24-28.

Anonymous. 2018. Plant Production Statistics. - www.tuik.gov.tr.

Atalay İZ, Kılıç R, Anaç D, Yokaş İ. 1986. Gediz havzası rendzina topraklarının potasyum durumu ve bu topraklarda alınabilir potasyum miktarının tayininde kullanılacak yöntemler. Bilge Matbaası, İzmir, s. 25 (in Turkish).

Aydeniz A, Teceren M, Dündar M. 1977. Domates veriminde tavuk dışkısının yeri ve 2-Kloro- 6 (Triklorometil ) pridinin buna Etkisi. A:Ü:Z:F.27;23-25.

Ayed A. 2002. Effect of chicken manure, sheep manure and inorganic fertilizer on yield and nutrient uptake by onion. Pakistan Jour. of Biological Science 5(3): 266-268.

Aydeniz A, Brohi AR. 1991. Gübreler ve Gübreleme. C. Ü. Ziraat Fak. Yay. No: 10, Ders Kitab 1 no: 3 , Tokat.

Bergmann W. 1993. Ernährungsstörungen bei Kulturpflanzen. Dritte erweiterte Auflage, Gustav Fisher Verlag JenaStutgart, ISBN 3-334-60414-4, pp: 1-835.

Bhuma M. 2001. Studies on the impact of humic acid on sustenance of soil fertility and productivity of greengram. MSc (Ag) Thesis. TNAU. Coimbatore.
Ceylan Ş, Yoldaş F, Çakıcı H, Mordoğan N. 2005. Effect of Farmyard Manure Application on Yield Quality and Nutrient Content of Watermelon. Journal of Balkan Ecology, Volume 8, No: 2, p. 175-179.

Ceylan Ş, Mordoğan N, Çakıcı H, Günen E, Çolak Esetlili B. 2016. Effect of Organic Fertilization on Macro Element Content, Yield and Some Quality Properties of Olive. Ege Journal of Agricultural Research (EJAR) 53(4): 389-395.

Ceylan Ş, Yoldaş F, Mordoğan N, Tepecik M. 2017. Effects of Organic Fertilizer on Nitrate Accumulation and Nutrient Element Content of Lettuce. Acta Biologica Turcica 30 (4): 164-168.

Chope GA, Terry LA. 2009. Use of canonical variate analysis to differentiate onion cultivars by mineral content as measured by ICP-AES. Food chemistry, Volume 115, Issue 3, 1 August 2009, Pages 1108-1113.

Davis AS, Jacobs DF, Wightman KE. 2006. Organic matter amendment of fallow forest tree seedling nursery soils influences soil properties and biomass of sorghum cover crop. Purdue University, West Lafayette, IN

Dikinya O, Mufwanzala N. 2010. Chicken manure-enhanced soil fertility and productivity: Effects of application rates. Journal of Soil Science and Environmental Management Vol. 1(3): pp. 46-54.

Eleroğlu H, Korkmaz K. 2016. Farklı organik gübrelerin tohumluk patates (Solanum tuberosum L.) çeşitlerinde verim ve kalite üzerine etkileri, Türk Tarım Gıda Bilim ve Teknoloji Dergisi 4(7): 566-578.

Eghball B, Shanahan JF, Varvel GE, Gilley JE. 2003. Reduction of high soil test phosphorus by corn and soybean varieties. Agron. J. 95: 1233-1239

Ginting D, Kessavalou A, Eghball B, Doran JW. 2003. Greenhouse gas emissions and soil indicators four years after manure and compost applications.J.Env.Qual.32: 23-32.

Jones JR, Wolf B, Mills HA. 1991. Plant Analyses Handbook. Micro Macro Publishing, Inc.

Kacar B. 1972. Chemical Analysis of plant and soil II. Plant analysis. Ankara University, Journal of Faculty of Agriculture. No: 453: 453.

Kidanu YG. 2017. Effect of Integrated Nutrient Management on Growth, Bulb Yield and Storability of Onion (Allium Cepa L.) Under Irrigation at Selekleka, Northern Ethiopia. - M.Sc. Thesis, 111 Pages. February 2017, Haramaya University, Haramaya.

Klute A. 1986. Methods of Soil Analysis. Part 1. Physical and Mineralogical Methods. 2nd Ed. Agron. Monogr. 9. - ASA and SSSA, Madison, WI.

Lindsay WL, Norvell WA. 1978. Development of a DTPA soil test for zinc, iron, manganese and copper. - Soil Science Society of American J. (42): 421-428.

Lott WL, Nery JP, Gall JR, Medcoff JC. 1956. Leaf Analysis Techniques in Coffee Research. IBEC Research Inst. Bulletin No: 9. Publish.

Lund ZF, Doss BD. 1980. Residual effects of dairy cattle manure on plant growth and soil properties. Agron. J. 72: 123-130.

Mahmoud RA, EL-Desuki M, Abdel-Mouty MM, Ali AH. 2013. Effect of compost levels and yeast extract application on the pea plant growth, pod yield and quality. J. Appl. Sci. Res., 9 (1): 149-155.

Munoz J. 1968. Atomic Absorption Spectroscopy and Analysis by Atomic Absorption Flame Photometry - Elsevier Publishing Company.

Murphy BW. 2014. Effects of soil organic matter on functional soil properties. Brain W. Murphy. Soil Scientist, Cowra, p: 129, GRDC

Page AL, Miller RH, Keeney DR. 1982. Methods of Soil Analysis. Part 2. Chemical and Microbiological Properties. 2 nd Ed. Agron. Monogr. 9. - ASA.

Sezen Y. 1995. Soil Chemistry. Edition of Ataturk University No: 790. - Atatürk Univ., Faculty of Agriculture, Erzurum, Turkey. 
Shaheen A, Fatma M, Rizk A, Singer SM. 2007. Growing onion plants without chemical fertilization. - Res. J. Agr. Biol. Sci. 3(2): 95-104.

Shaymaa I, Shedeed SA, EL-Sayed A, Doaa M, Abo Bash. 2014. Effectiveness of bio-fertilizers with organic matter on the growth, yield and nutrient content of Onion (Allium cepa L.) plants. European International Journal of Science and Technology, Vol. 3 No. 9.115-122.

Snyman HG, Jong DE, Aveling TAS. 1998. The stabilization of sewage sludge applied to agricultural land and the effects on maize seedlings. Water Sci. Technol. 38 (2): 87-95.

Suthamathy N, Seran TH. 2013. Residual effect of Organic manure EM Bokashi applied to Proceeding Crop of Vegetable Cowpea (Vigna unguiculata) on succeeding Crop of Radish (Raphanus sativus). Research Jour. of Agri. and For. Sci.Vol. 1(1): 2-5.

Yassen AA, Khalid KhA. 2009. Influence of organic fertilizers on the yield, essential oil and mineral content of onion. Int. Agrophysics, 23: 183-188.
Yoldas F, Ceylan Ş, Mordogan N, Esetlili BC. 2011. Effect of organic and inorganic fertilizers on yield and mineral content of onion (Allium cepa L.). African Journal of Biotechnology, vol.10, no.55, pp.11488-11492

Yoldas F, Ceylan S, Mordoğan N. 2019. Residue effect of chicken manure on yield and yield criteria of onion (Allium cepa L.) as second crop - Applied Ecology and Environmental Research 17(5):12639-12647. ISSN 15891623 (Print). ISSN 17850037 (Online) DOI: http://dx.doi.org/10.15666 /aeer/1705_1263912647 (C) 2019.

Yoldas F, Ceylan S, Mordoğan N. 2020. Residual effect of organic manure and recommended NPK fertilizer on yield and bulb performance of onion (Allium cepa L.) as second crop under greenhouse conditions. Applied Ecology and Environmental Research 18(1): 303-314. http://www.aloki.hu ISSN 15891623 (Print). ISSN1785 0037 (Online) DOI: http://dx.doi.org/10.15666/aeer/1801_303314. Whitmore AP. 2007. Determination of the mineralization of nitrogen from composted chicken manure as affected by temperature. Nutr. Cycl. Agroecosyst. 77: 225-232. 